\title{
Analysis of risk factors in surgical site infection following caesarean section
}

\author{
Anam ul Haq ${ }^{1 *}$, Aasif Abdullah', Shazieya Akhtar ${ }^{2}$ \\ ${ }^{1}$ Department of Obstetrics and Gynaecology, SKIMS Soura, Srinagar, Jammu and Kashmir, India \\ ${ }^{2}$ Department of Pathology, SKIMS Soura, Srinagar, Jammu and Kashmir, India
}

Received: 10 September 2016

Revised: 13 October 2016

Accepted: 15 October 2016

\section{*Correspondence:}

Dr. Anam ul Haq,

E-mail: anamulhaq801@gmail.com

Copyright: $\odot$ the author(s), publisher and licensee Medip Academy. This is an open-access article distributed under the terms of the Creative Commons Attribution Non-Commercial License, which permits unrestricted non-commercial use, distribution, and reproduction in any medium, provided the original work is properly cited.

\begin{abstract}
Background: Objective of the study was to find SSI rate following Caesarean section and Analysis of risk factors.

Methods: This prospective randomized study carried out on 1504 patients, their demographic information, risk factors and surgical indications were recorded. Postoperatively patients were monitored for signs of SSI.

Results: Out of 1504 patients, 13\% developed SSI, Hospital stay, wound class, ASA class, antibiotic prophylaxis and Type of caesarean showed significant association with SSI.

Conclusions: Reason for incidence of SSI higher than developed countries being only tertiary care hospital dealing with high risk pregnancies, late referrals from peripheries, Prolonged hospital stay, heavy rush of attendants, faulty supervision where dose of antibiotics is actually missed, no proper segregation of cases.
\end{abstract}

Keywords: ASA class, Hospital stay, SSI, Wound class

\section{INTRODUCTION}

Infection is the clinical manifestation of the inflammatory reaction incited by invasion and proliferation of microorganisms. ${ }^{1}$ SSI is the second most common infectious complication after urinary tract infection following caesarean delivery. ${ }^{2}$ The rates of SSI after caesarean section reported in the literature range from $3 \%$ to $15 \%$ depending on the surveillance method used to identify infections, the patient population and the use of antibiotic prophylaxis. ${ }^{3-9}$ Maternal morbidity related to infections has been shown to be eight fold higher after caesarean section than after vaginal delivery. ${ }^{10}$ Among hospitals reporting to the National Nosocomial Infections (NNIS) system, the rate of SSI after caesarean section was $2.8 \%$ to $6.7 \%$ depending on the risk index category. ${ }^{11}$ The incidence rate depends on the following: the definition of SSI adopted, the intensity of surveillance, the prevalence of risk factors for SSI in the patient group being audited and whether the survey contains post discharge data[12].Post discharge surveillance has become increasingly important to obtain accurate rates of SSI.

\section{Criteria for defining surgical site infections}

\section{Superficial incisional SSI}

Infection occurs within 30 days after operation and infection involves only skin or subcutaneous tissue of the incision and at least one of the following.

1. Purulent discharge from the superficial incision.

2. Organisms isolated from the superficial incision.

3. At least one of these signs or symptoms of infection: Pain or tenderness, swelling, redness or heat and superficial incision are deliberately opened by surgeon, unless incision is culture negative.

4. Diagnosis of superficial incisional SSI by the surgeon or physician. 


\section{Deep incisional SSI}

Infection occurs within 30 days after operation if no implant is left in place or within one year if implant is in place and the infection appears to be related to the operation and infection involves deep soft tissues of the incision and at least one of the following:

1. Purulent drainage from the deep incision but not from the organ/space component of the surgical site.

2. A deep incision spontaneously dehices or is deliberately opened by a physician when the patient has atleast one of these signs or symptoms of infection: fever, localized pain or tenderness, unless the site is culture negative.

3. An abscess or other evidence of infection involving the deep incision is found.

4. Diagnosis of a deep incisional SSI by a surgeon or physician.

\section{Organ/space SSI}

Infection occurs within 30 days after operation if no implant is left in place or within one year if implant is in place and the infection appears to be related to the operation and infection involves any part of the anatomy, other than the incision, which was opened or manipulated during an operation and at least one of the following:

1. Purulent drainage from a drain that is placed through a stab wound into the organ/space

2. Organisms isolated from fluid or tissue in the organ/space.

3. An abscess or other evidence of infection is found.

4. Diagnosis or an organ/space SSI by a surgeon or physician.

\section{Determinants of infection}

1. Inoculum of bacteria

2. Virulence of bacteria

3. Adjuvant effects of microenvironment

4. Innate and acquired host defences

Risk factors for wound infection

\section{Host related factors}

Socioeconomic status: Low socioeconomic status has consistently been associated with higher rates of post caesarean infection. ${ }^{14-16}$

Preterm delivery: Preterm delivery is a known risk factor for sepsis; also many preterm deliveries are emergencies. ${ }^{17}$

Rupture of membranes: One factor repeatedly linked to post caesarean infectious morbidity is prolonged rupture of the membranes because of more chances of contamination.
Vaginal examinations: Prolonged labour increases the number of vaginal examinations which predisposes the patient to post-partum infection. ${ }^{18}$

\section{Surgery related factors}

\section{Emergency}

Women who underwent an emergency caesarean delivery for indications such as placental abruption, nonreassuring fetal heart rate and non progressing second stage of labour were more likely to develop a wound infection. ${ }^{19}$

\section{American society of anaesthesiologists score}

The American Society of Anaesthesiologists physical status classification is a standardized, reproducible numeric determination that is used routinely to stratify severity of illness for surgical patients and is known to be a good indicator of host susceptibility to infection. ${ }^{20,21}$

\section{Duration of operation}

Patients who underwent surgery for more than one hour constituted another group at risk of infection. ${ }^{22,3}$

\section{Antibiotic prophylaxis}

Prophylactic antibiotics will reduce the incidence of endometritis following both elective and non-elective caesarean delivery by two thirds to three quarters and the incidence of wound infection by up to three quarters. ${ }^{7}$

\section{METHODS}

This study was a prospective design study conducted on 1504 patients selected randomly from August 2014 to October 2015 in Lalla Ded Hospital Srinagar J and K.

\section{Inclusion criteria}

1. Patients who had undergone caesarean in this hospital

\section{Exclusion criteria}

1. Any patient operated elsewhere

Purpose of study was explained to patients, and their verbal consent taken.

\section{Data collection}

Demographic information, potential risk factors and surgical indications were recorded.

Postoperatively women were monitored for signs of infection. Temperature was measured every day and leukocyte count was done if the patient developed fever 
(temp over $38.0^{\circ} \mathrm{C}$ ). Wound culture was not done routinely unless infection was suspected.

The surgical site was considered infected if pus was found anywhere along the suture line with or without dehiscence.

\section{Data analysis}

Data was expressed as Mean \pm SD and percentages. Critical difference of variance for metric data was measured at $95 \%$ confidence interval by students ' $t$ ' test. Non metric data was similarly analysed by Fisher's exact test, Mann-Whitney ' $U$ ' test, besides logistic regression analysis was done for determining best predictors along with Odds ratio analysis. $\mathrm{P} \leq 0.05$ considered statistically significant. Statistical SPSS, Mini Tab and MS Excel were used for data analysis.

\section{Definitions}

American Society of Anaesthesiologists Score (ASA)

- $\quad$ Class I - Normally healthy patient.

- Class II - Mild systemic disease.

- Class III - Severe systemic disease.

- Class IV - Incapacitating systemic disease that is threat to life.

- Class V - Morbid patient who is not expected to survive 24 hours.

\section{Wound class}

- Class I - No rupture of membranes or labour.

- Class II - If there was less than 2 hours of membrane rupture without labour or labour of any length with intact membranes.

- $\quad$ Class III - For rupture of membranes greater than 2 hours.

- $\quad$ Class IV - For purulent amniotic fluid.

\section{RESULTS}

Demographic information, potential risk factors and surgical indications were recorded.

Host related variables included age, preoperative diagnosis, a preoperative condition assessed by American Society of Anaesthesiologists (ASA) score and total hospital stay.

Surgery related variables included nature of the operation, wound class and antibiotic prophylaxis.

Majority of the cases $(51.7 \%)$ were in age group of 25 to 29 years, whereas $27 \%$ were $\leq 24$ years; $18.9 \%$ between $30-34$ years and $2.5 \%$ cases were $\geq 35$ years.
Majority of cases (45.9\%) had class I wound, whereas $21.6 \%$ had class II wound; $27.1 \%$ had class III wound and $5.4 \%$ had class IV wound.

Majority of cases (48.2\%) were with mild systemic disease, whereas $33.8 \%$ were normally healthy, $12.8 \%$ with severe systemic disease and $5.3 \%$ with incapacitating systemic disease.

Majority of caesareans (66.3\%) were emergency and $(33.7 \%)$ were elective.

Maximum number of cases (88.9\%) had received prophylactic antibiotics whereas (11.1\%) had not received any prophylactic antibiotics.

Majority of cases had superficial (64.1\%) whereas $(24.6 \%)$ had deep and $(11.3 \%)$ had organ/space SSI.

Table 1: Various risk factors of SSI.

\begin{tabular}{|c|c|c|c|}
\hline & & n & $\%$ \\
\hline \multirow{5}{*}{ Age (yr) } & $\leq 24$ & 406 & 27.0 \\
\hline & 25 to 29 & 777 & 51.7 \\
\hline & 30 to 34 & 284 & 18.9 \\
\hline & $\geq 35$ & 37 & 2.5 \\
\hline & mean \pm SD & $26.9 \pm$ & $(18,40)$ \\
\hline \multirow{4}{*}{ Wound Class } & Class I & 690 & 45.9 \\
\hline & Class II & 325 & 21.6 \\
\hline & Class III & 408 & 27.1 \\
\hline & Class IV & 81 & 5.4 \\
\hline \multirow{4}{*}{$\begin{array}{l}\text { ASA } \\
\text { classification }\end{array}$} & Normally healthy & 508 & 33.8 \\
\hline & $\begin{array}{l}\text { Mild Systemic } \\
\text { Disease }\end{array}$ & 725 & 48.2 \\
\hline & $\begin{array}{l}\text { Severe systemic } \\
\text { disease }\end{array}$ & 192 & 12.8 \\
\hline & $\begin{array}{l}\text { Incapacitating } \\
\text { systemic disease }\end{array}$ & 79 & 5.3 \\
\hline \multirow{2}{*}{$\begin{array}{l}\text { Prophylactic } \\
\text { antibiotics } \\
\text { given? }\end{array}$} & No & 167 & 11.1 \\
\hline & Prior to Incision & 1337 & 88.9 \\
\hline \multirow{2}{*}{ Operation type } & Elective & 507 & 33.7 \\
\hline & Emergency & 997 & 66.3 \\
\hline \multirow{3}{*}{ Type of SSI } & Superficial & 125 & 64.1 \\
\hline & Deep & 48 & 24.6 \\
\hline & Organ/Space & 22 & 11.3 \\
\hline \multirow{5}{*}{$\begin{array}{l}\text { Total hospital } \\
\text { stay (day) }\end{array}$} & 16 to 30 days & 12 & 0.8 \\
\hline & 4 to 7 days & 594 & 39.5 \\
\hline & 8 to 15 days & 630 & 41.9 \\
\hline & 16 to 30 days & 268 & 17.8 \\
\hline & $>30$ days & 12 & 0.8 \\
\hline \multirow{2}{*}{$\begin{array}{l}\text { Surgical Site } \\
\text { Infection (SSI) }\end{array}$} & Yes & 195 & 13.0 \\
\hline & No & 1309 & 87.0 \\
\hline
\end{tabular}

Majority of cases (41.9\%) had total hospital stay of 8 to 15 days, whereas $(39.5 \%)$ had total hospital stay of 4 to 7 days, $17.8 \%$ stay of 16 to 30 days and $0.8 \%$ stay of more than 30 days. 
Out of total 1504 cases 195 developed SSI and rate was $13 \%$ (Table 1).

In our study $(8.3 \%)$ cases developed SSI out of 690 cases of class I wound, $(14.2 \%)$ developed SSI out of 325 cases of class II wound; (18.1\%) developed SSI out of 408 cases of class III wound and $(22.2 \%)$ developed SSI out of 81 cases of class IV wound. The above results depict SSI is more prevalent in contaminated wound class with $P$ value of 0.000 which is statistically significant $(\mathrm{p}<0.05)$ [OR 2.01] (Table 2).

In ASA classification of patients (9.4\%) developed SSI among 508 cases that were normally healthy; (13.5\%) among 725 cases who had mild systemic disease; $(6.7 \%)$ among 192 cases that had severe systemic disease and
(21.5\%) developed SSI out of 79 cases that had incapacitating systemic disease. The above results depict that SSI is more prevalent in cases associated with morbidity with higher class ASA, with $\mathrm{P}$ value being 0.000 , which is statistically significant $(\mathrm{P}<0.05)$; [OR 1.92] (Table 3).

Table 2: Association of wound class with SSI.

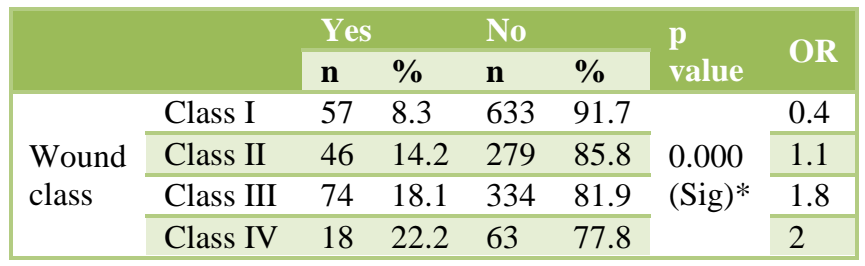

* Significant

Table 3: Association of ASA with SSI.

\begin{tabular}{|c|c|c|c|c|c|c|c|}
\hline & & \multicolumn{2}{|c|}{ Yes } & \multicolumn{2}{|l|}{ No } & \multirow{2}{*}{ p value } & \multirow{2}{*}{ OR } \\
\hline & & $\mathbf{n}$ & $\%$ & $\mathbf{n}$ & $\%$ & & \\
\hline \multirow{4}{*}{ ASA classification } & Normally healthy & 48 & 9.4 & 460 & 90.6 & \multirow{4}{*}{$\begin{array}{l}0.000 \\
(\mathrm{Sig})^{*}\end{array}$} & 0.6 \\
\hline & Mild systemic disease & 98 & 13.5 & 627 & 86.5 & & 1.1 \\
\hline & Severe systemic disease & 32 & 16.7 & 160 & 83.3 & & 1.4 \\
\hline & Incapacitating systemic disease & 17 & 21.5 & 62 & 78.5 & & 1.9 \\
\hline
\end{tabular}

* Significant

Table 4: Association of prophylactic antibiotics.

\begin{tabular}{|c|c|c|c|c|c|c|}
\hline \multirow{2}{*}{$\begin{array}{l}\text { Prophylactic } \\
\text { antibiotics } \\
\text { given }\end{array}$} & \multicolumn{2}{|l|}{ Yes } & \multicolumn{2}{|l|}{ No } & \multirow[b]{2}{*}{$\begin{array}{l}\mathrm{p} \\
\text { value }\end{array}$} & \multirow[b]{2}{*}{ OR } \\
\hline & $\mathbf{n}$ & $\%$ & n & $\%$ & & \\
\hline No & 46 & 27.5 & 121 & 72.5 & \multirow[b]{2}{*}{$\begin{array}{l}0.000 \\
(\mathrm{Sig})^{*}\end{array}$} & 5.1 \\
\hline $\begin{array}{l}\text { Prior to } \\
\text { incision }\end{array}$ & 149 & 11.1 & 1188 & 88.9 & & 0.2 \\
\hline
\end{tabular}

Among 167 cases who had not received prophylactic antibiotics, (27.5\%) developed SSI while out of 1337 cases who had received prophylactic antibiotics, $(11.1 \%)$ developed SSI. The above results depict that SSI is more prevalent in cases who had not received prophylactic antibiotics, with a $\mathrm{P}$ value of 0.000 , which is statistically significant ( $\mathrm{p}<0.05)$; [OR 3.03] (Table 4).

Operation type showed that among 507 elective cases, 8.7\% developed SSI while from 997 emergency cases, $15.1 \%$ developed SSI. The results depict that SSI is more prevalent in emergency caesareans with a $\mathrm{P}$ value being 0.000 , which is statistically significant $(\mathrm{P}<0.05)$ [OR 1.88] (Table 5).

Table 5: Association of operation type with SSI.

\begin{tabular}{|c|c|c|c|c|c|c|c|}
\hline & & \multicolumn{2}{|l|}{ Yes } & \multicolumn{2}{|l|}{ No } & \multirow{2}{*}{ p value } & \multirow{2}{*}{ OR } \\
\hline & & $\mathrm{n}$ & $\%$ & n & $\%$ & & \\
\hline \multirow{2}{*}{ Operation type } & Elective & 44 & 8.7 & 463 & 91.3 & \multirow{2}{*}{$0.000(\mathrm{Sig})^{*}$} & 0.5 \\
\hline & Emergency & 151 & 15.1 & 846 & 84.9 & & 1.9 \\
\hline
\end{tabular}

* Significant

Table 6: Association of hospital stay with SSI.

\begin{tabular}{|c|c|c|c|c|c|c|c|}
\hline & & \multicolumn{2}{|l|}{ Yes } & \multicolumn{2}{|l|}{ No } & \multirow{2}{*}{ p value } & \multirow{2}{*}{ OR } \\
\hline & & $\mathbf{n}$ & $\%$ & $\mathbf{n}$ & $\%$ & & \\
\hline \multirow{4}{*}{$\begin{array}{l}\text { Total hospital stay } \\
\text { (day) }\end{array}$} & 4 to 7 days & 28 & 4.7 & 566 & 95.3 & \multirow{4}{*}{$0.000(\mathrm{Sig})^{*}$} & 0.2 \\
\hline & 8 to 15 days & 52 & 8.3 & 578 & 91.7 & & 0.5 \\
\hline & 16 to 30 days & 103 & 38.4 & 165 & 61.6 & & 7.8 \\
\hline & $>30$ days & 12 & 100.0 & 0 & 0.0 & & 171.7 \\
\hline
\end{tabular}

\footnotetext{
* Significant
} 
Out of 594 cases who had total hospital stay of 4 to 7 days, $4.7 \%$ developed SSI; 630 cases who had total hospital stay of 8 to 15 days, $8.3 \%$ developed SSI; 268 cases who had total hospital stay of 16 to 30 days, $38.4 \%$ developed SSI and among 12 cases who had total hospital stay more than 30 days, $100 \%$ developed SSI. The above results depict that SSI is more prevalent in cases with prolonged hospital stay with $\mathrm{P}$ value of $\mathrm{P}=0.000$; $[\mathrm{OR}$ 171.60] which is statistically significant (Table 6).

\section{DISCUSSION}

The overall abdominal wound infection rate of $13 \%$ is comparable with other studies that have used post discharge surveillance. Similar findings were observed by Barbut F, Carbonne B, Truchot F et al and Mitt P, Lang $\mathrm{K}$, Peri A et al, which found significant percentage of SSI is detected by post discharge surveillance. ${ }^{23,24}$

Due to referrals from other hospitals, patients fall in higher wound class either because of prolonged labour, prolonged rupture of membranes or obstructed labour which is a potent risk factor for SSI when caesarean section is done.

In our study Among 690 cases of class I wound, 8.3\% developed SSI. Out of 325 cases of class II wound, $14.2 \%$ developed SSI. Among 408 cases of class III wound, $18.1 \%$ developed SSI and from 81 cases of class IV wound, $22.2 \%$ developed SSI. The above results depict that SSI is more prevalent in cases with more contaminated wound class. Similar findings were observed by Eriksen H, Saether AR et al, Amenu Demisew, Tefera Belachew et al, Mitt $\mathrm{P}$ et al, Jido TA, Garba ID et al, Killian CA et al, and Schneid Kofman N et al which showed significant association between surgical wound class and SSI. ${ }^{3,19,24-27}$

Our hospital being a sole tertiary care hospital in valley and most of the patients who are referred from pheripheries are usually high risk pregnancies with higher ASA class, which is a significant risk factor for SSI. In our study, Out of 508 normally healthy cases $(9.4 \%)$ developed SSI. Among 725 cases with mild systemic disease $(13.5 \%)$ developed SSI, Within 192 cases of severe systemic disease, $(16.7 \%)$ developed SSI and from 79 cases who had incapacitating systemic disease, $(21.5 \%)$ developed SSI. The above results depict that SSI is more prevalent in cases associated with morbidity. Similar findings were observed by Tran ST et al and Barbut F, Carbonne B, Truchot et al, which showed significant association between ASA class and SSI. ${ }^{4,23}$

Numerous studies have recommended that antibiotic prophylaxis be given to all caesarean delivery cases for prevention of serious infections.

In our hospital we have a protocol of giving antibiotic prophylaxis to all women undergoing caesarean section. We found all elective caesareans had received prophylaxis before procedure, but it was found that not all emergency caesareans had received prophylaxis before procedure; reason was either nursing staff had not given or it was not prescribed on case sheet. Results from our study showed among 167 cases who had not received prophylactic antibiotics, $(27.5 \%)$ developed SSI and out of 1337 cases who had received prophylactic antibiotics $(11.1 \%)$ developed SSI. The above results depict that SSI is more prevalent in cases who had not received prophylactic antibiotics. Similar findings were observed by Beattie, Rings TR et al, Owens SM et al and Killian CA et al. ${ }^{3,28,29}$

Emergency caesarean sections are done usually when patient is in labour; mostly membranes are absent, increased number of vaginal examinations and sometimes miss the dose of prophylactic antibiotics. All these are potent risk factors for infection. In our study $8.7 \%$ developed SSI, out of 507 elective caesareans and $15.1 \%$ developed SSI out of 997 emergency caesareans. SSI was more prevalent in emergency caesareans with $\mathrm{P}$ value being 0.000; [OR 1.9] which is statistically significant $(p<0.05)$. The above results are consistent with studies of Schneid-Kofman $\mathrm{N}$ et al and Amenu Demisew, Tefera Belachew et al. ${ }^{19,26}$

Prolonged stay in hospital means more chances of infection because of cross infection by health care workers, poor sanitation and poor asepsis. In our study out of 594 cases who had total hospital stay of 4 to 7 days, $4.7 \%$ developed SSI; 630 cases who had total hospital stay of 8 to 15 days, $8.3 \%$ developed SSI; 268 cases who had total hospital stay of 16 to 30 days, $38.4 \%$ developed SSI and among 12 cases who had hospital stay more than 30 days, $100 \%$ developed SSI. The above results depict that SSI is more prevalent in cases with prolonged hospital stay with $\mathrm{P}=0.000$ [OR 171.60] which is statistically significant. The above results are consistent with the study of Nisa M, Naz T, Afzal I et al. ${ }^{30}$

\section{CONCLUSION}

The caesarean delivery rate has been steadily increasing over the last 30 years and it is common for major centres to have a rate in double figures. The development of a wound infection after caesarean delivery is a morbid event and may result in significant patient discomfort, inconvenience, embarrassment, prolonged hospital stay, additional surgery and increased cost of community care following discharge.

Incidence of SSI was (13\%) following caesarean section which is higher than developed countries.

Statistically significant risk factors for SSI include wound class, ASA class, Antibiotic prophylaxis and operation type and total hospital stay.

The various reasons for such increased rate of SSI are: 
1. Only tertiary care institute dealing with high risk pregnancies.

2. Late referrals.

3. Prolonged hospital stay of those cases where in hospital stay is must.

4. Heavy rush of attendants and inadequacy of bed strength.

5. Faulty supervision where dose of antibiotics is actually missed before caesarean.

6. No proper segregation of infected from healthy cases.

7. Attempting home deliveries by dai's

8. Culture and taboos of not bathing for six weeks still prevalent in our community.

The interventions which are expected to decrease SSI rate are:

1. Decrease hospital stay

2. Educating women about cleanliness

3. Antibiotic prophylaxis to all before procedure

4. Separate labour room for septic patients

5. Limiting attendants rush

6. Early referral of cases where chances of caesarean are high.

7. Educating people about $100 \%$ institutional deliveries

8. Importance of post discharge surveillance.

Funding: No funding sources

Conflict of interest: None declared

Ethical approval: The study was approved by the Institutional Ethics Committee

\section{REFERENCES}

1. Mollit D, Ziegler MA. Operative Pediatric Surgery. McGraw-HILL; 2003:161-178.

2. Hillian J. Post-operative morbidity following caesarean delivery. J Adv Nurs. 1995;22:1035-42.

3. Killian CA, Graffunder EM, Vinciguerra TJ, Venezia RA. Risk factors for surgical site infections following caesarean section. Infection Control and Hospital Epidemiology. 2001;22(10):613-7.

4. Tran TS, Jamulitrat S, Chongsuvivatwong V, Greater A. Risk factors for postcaesarean surgical site infection. Obstetrics and Gynaecology. 2000;95(3):367-371.

5. Lasley DS, Eblen A, Yancey MK, Duff P. The effect of placental removal method on the incidence of post caesarean infections. Am J Obstet Gynaecol. 1997;176:1250-54.

6. Cooper NJ, Sutton AJ, Abrams KR. Decision analytical economic modeling within a Bayesian framework: application to prophylactic antibiotics use for caesarean section. Stat Methods Med Res. 2002;11:491-512.

7. Smaill F, Hofmeyr GJ. Antibiotic prophylaxis for caesarean section (Review).The Cochrane Database of Systematic Reviews. 2006;(3):CD000933.
8. Yokoe DS, Christiansen CL, Johnson R. Epidemiology of and surveillance for postpartum infections. Emerg Infect Dis. 2001;7:837-41.

9. Yokoe DS, Noskin GA, Cunningham SM. Enhanced identification of postoperative infections. Emerg Infect Dis. 2004;10:1924-30.

10. Ott WJ. Primary caesarean section: Factors related to postpartum infection. Obstetrics and Gynaecology. 1981;57:171-6.

11. National Nosocomial Infections Surveillance System. National Nosocomial infections Surveillance [NNIS] System Report, data summary from January 1992 through June 2004, issued October 2004. Am J Infect Control. 2004;32:470-85.

12. Smyth ET, Emmerson AM. Surgical site infection surveillance. J Hosp Infect. 2000;45:173-84.

13. Mangram AJ, Horan TC, Pearson ML, Silver LC, Jarvis WR. Guideline for prevention of surgical site infection. Hospital Infection Control Practices Advisory Committee. Infect Control Hosp. Epidemiol. 1999;20:250-78.

14. Henderson E, Love EJ. Incidence of hospital acquired infections associated with caesarean section. Journal of Hospital Infection. 1995;29:24555.

15. Blanco JD, Gibb RS, Castaneda YS, St Clair PJ. Correlation of quantitative fluid cultures with endometritis following caesarean section. American Journal of Obstetrics and Gynecology. 1982;143:897-901.

16. Apuzzio JJ, Reyelt C, Pelosi M, Purnendu S, Louria DB. Prophylactic antibiotics for caesarean section: comparison of high and low risk patients for endomyometritis. Obstetrics and Gynaecology 1982;59:693-8.

17. King C. Infection following caesarean section: A study of the literature and cases with emphasis on prevention. The Central African Journal of Medicine. 1989 Dec;35(12):556-70.

18. Imseis HM, Trout WC, Gabbe SG. The microbiologic effect of digital cervical examination. American Journal of Obstetrics and Gynaecology. 1999; 180:578-580.

19. Schneid-Kofman N, Sheiner E, Levy A, Holcberg G. Risk factors for wound infection following caesarean deliveries. International Journal of Gynaecology and Obstetrics. 2005 Mar;90:10-5.

20. Owens WD, Felts JA, Spitznagel EL. ASA physical status classification: A study of consistency of ratings. Anaesthesiology. 1978;49:239-43.

21. Garibaldi RA, Cushing D, Lerer T. Predictors of intraoperative acquired surgical wound infections. Journal of Hospital Infection. 1991;189(A):289-98.

22. Koigi-Kamau R, Kabare LW, Wanyoike-Gichuhi J. Incidence of wound infection after caesarean delivery in a district hospital in Central Kenya. East African Medical Journal. 2005;82(7):357-61.

23. Barbut F, Carbonne B, Truchot F, Spielvogel C, Jannet D, Goderel I. Surgical site infections after caesarean section: results of a five year prospective 
surveillance. J Gynecol Obstet Biol Reprod. 2004 Oct;(396):487-96.

24. Mitt P, Lang K, Peri A, Maimets M. Surgical site infections following caesarean section in an Estonian university hospital: postdischarge surveillance and analysis of risk factors. Infect Control Hosp Epidemiol. 2005;26:449-54.

25. Eriksen HM, Saether AR, Lower HL, Vangen S, Hjetland $\mathrm{R}$, Lundmark $\mathrm{H}$, et al. Infections after caesarean sections. Tidsskr Nor Legeforen. 2009;129:618-22.

26. Amenu D, Belachew T, Araya F. Surgical Site Infection Rate and Risk Factors Among Obstetric Cases of Jimma University Specialized Hospital, Southwest Ethiopia. Ethiop J Health Sci. 2011 July;21(2):91-100.
27. Jido TA, Garba ID. Surgical site infection following caesarean section in Kano, Nigeria. Ann Med Health Sci Res. 2012;2:33-6.

28. Beattie PG, Rings TR, Hunter MF, Lake Y. Risk factors for wound infection following caesarean section. Aust N Z J Obstet Gynaecol. 1994 Aug;34(4):398-402.

29. Owens SM, Brozanski BS. Antimicrobial prophylaxis for caesarean delivery before skin incision. Obstet Gynaecol. 2009 Sep;114(3):573-9.

30. Nisa M, Naz T, Afzal I, Hassan L. Scope of surgical Site Infection [SSI] in Obstetrics and Gynaecology. JPMI. 2005;19(4):438-41.

Cite this article as: Haq AU, Abdullah A, Akhtar S. Analysis of risk factors in surgical site infection following caesarean section. Int J Reprod Contracept Obstet Gynecol 2016;5:4256-62. 